\title{
Canteen Management in Public Secondary High Schools of Zone Ii, Division of Zambales
}

\author{
Jerwin E. Acilo, Esmen M. Cabal
}

\begin{abstract}
The study was conducted to assess the School Canteen Management in Public Secondary High Schools of Zone II, Division of Zambales for the SY 2018-2019.The research utilized descriptive research design and questionnaire as the main instrument in gathering data supplemented by unstructured interviews from one hundred forty two students and one hundred seventeen faculty, parents and canteen operators who were randomly selected. The researcher found out that most of the teachers, parents and canteen owners are adults; female and married. Their monthly family income is meager. Generally they finished high school but majority of them have their BS degree with masteral units and doctorate degree. They belong to Roman Catholics as to their religious affiliation. The canteen owners and teachers have a enough number of experience in the operation of canteen. The student-respondent is generally male, a teenager in Grade 11 and have small amount of money for school daily allowance. The canteen operators and students assessed that on permit and clearance, personnel and staff, price and commodities, food security and standards, quality and quantity of food served, kinds of service render to the customer, transparency and accountability, sharing and proceeds and reports and documentation are evident. There is significant difference on the perceptions of the teachers, parents and canteen operators towards school canteen management as to the evidence of permit and clearance, canteen personnel and staff, quality and quantity of food served, kinds of services rendered to the customers, transparency and accountability when they are group as to type of canteen they operate, age and years on the operation of the canteen and their highest education attainment; significant to age, length of years and type of canteen operation towards price and commodities; however there is a significant difference on their perceptions when they are grouped as to their highest educational attainment and type of canteen operation towards sharing and proceeds; and significant to highest educational attainment, length of years in the canteen operation and type of canteen operation towards report and documentation. There is significant difference on the perception of the teachers, parents, and canteen operators when grouped according to sex on the assessment towards dimension of canteen management as to permit and clearance, personnel and staff, price and commodities, food security and standards, quality and quantity of food served, kinds of service render to the customer, transparency and accountability. There is a significant difference in the perceptions of the teachers, parents and canteen operators towards the evidence in the permit and clearance and food security standard when grouped according to the type of canteen.
\end{abstract}

Manuscript received on July 03, 2021.

Revised Manuscript received on July 13, 2021.

Manuscript published on July 30, 2021.

* Correspondence Author

Jerwin E. Acilo*, MBA, Zambales National High School, President Ramon Magsaysay State University, Zambales, Philippines. Email: jerzy4113@gmail.com

Esmen M. Cabal, EdD, Zambales National High School, President Ramon Magsaysay State University, Zambales, Philippines. Email: cabalesmen0817@gmail.com

(C) The Authors. Published by Blue Eyes Intelligence Engineering and Sciences Publication (BEIESP). This is an open access article under the CC BY-NC-ND license (http://creativecommons.org/licenses/by-nc-nd/4.0/)

There is a significant difference in the perceptions of teachers, parents and canteen operators towards management evidences in canteen personnel and staff, price and commodities, quality and quantity of food served, kind of services rendered, transparency and accountability and sharing of proceeds when respondents were grouped according to length of years in operation and type of canteen operation with the inclusion of highest educational attainment towards the parameter of sharing proceeds. There is moderate relationship between the perceptions toward management evidences on price and commodities and the quality and quantity of food served as assessed by teacher, parent and canteen operator and student respondents. Based on salient findings and conclusions arrived, the researcher offers the following recommendations that the school heads should prepare a workable and viable long range master plan on canteen operations and personnel functions; the conduct a regular check-up or ocular visits on school canteens particularly on the kitchen area to assure sanitation and cleanliness in food handling is strongly encouraged; that the school officials should be ready to entertain and provide immediate action on complaints against mishandling of food and other concerns related to canteen operation; to provide discounts, combo meals at cheaper price; that the personnel incharge in cooking should look for organic alternatives of seasoning rather than the use so much amount of glutamate monosodium which affects health and safety condition of the students; that the canteen operators/school management should provide continuous training for crews and staff particularly those newly hired to assure safety on food handling and preparation and finally, future researchers may conduct a similar or parallel study with in-depth and wider in scope so as to validate the findings obtained in the study.

Keywords: Management, School, Students, Teachers

\section{INTRODUCTION}

The establishment and operation of a school canteen is important in developing love and interest in buying nutritious and healthy food among students, faculty and the school personnel, making it possible for them to enjoy nutritious and healthy food at affordable prices during the school day. The canteen should also provide a variety of foods and dishes that enhance the skill and knowledge learnt in the classroom about food and nutrition (Maniquiz, 2009).

The school canteen should be established to benefit children by making it possible for children to buy nutritious and healthy food at competitive prices, through providing a variety of food and dishes and charging prices which allow moderate profits. It is imperative that the principals, ensure the practice of serving the right kind of food for the students.

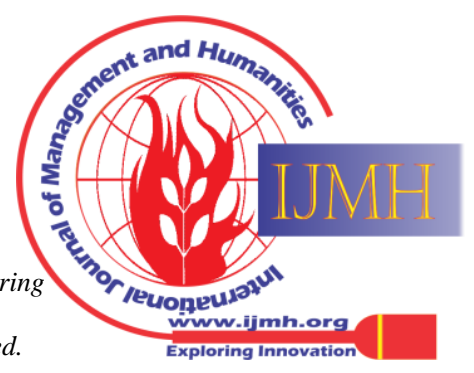


A canteen policy which has this as basis would be valuable as they encourage those in control of providing food to reduce health risks from poor nutrition is about having knowledge and skills, making healthy food choices, having healthy attitudes towards food, having access to healthy food choices and balance nutrition (Tasmanian School Canteen Handbook, 2014).

The school canteen should also serve as the showcase of skills and knowledge learned in the classroom about food and nutrition. It can also provide an avenue for parental involvement in the school by using volunteer workers in the school. It is the duty of the school and parents to educate students about nutrition. The school canteen as part of the school community is in a vantage position to make a positive contribution to student health.

The school canteen management should encourage the students to buy nutritious and healthy foods at affordable prices. They should prevent the school children from staying off the school campus during recess time and lunch break. Well prepared and clean food are vital feature of an efficiently run school canteen. It should also prepare food that is both appealing and nutritious for the students.

Facilities of the school are considered as one of the variables investigated in this study and the literature below given insight on this matter (Maniquiz, 2009).

\section{CONCEPTUAL FRAMEWORK (REVIEW OF RELATED LITERATURE)}

\section{Canteen Administration}

Dizon (2000) investigated the management of the school canteens in the district of Dinalupihan, Bataan, and their implications to the nutritional needs of the pupils. Based on the finding of this study, the following conclusions were drawn: Majority of the canteen was managed by private individuals. All canteen facilities and equipment were moderately adequate; Food procurement was supervised by outside paid helpers; The canteen managers saw to it that the food to be cooked are washed thoroughly; Majority of the canteens were implementing self-service food serving; and The problems in the operation of the canteens were lack of personnel, lack of time in food preparation, source of water supply and pupil's preference for junk foods instead of nutritious one.

Mendoza (2004) made a study on canteen administration and operation in public elementary schools in the division of Lipa city. The descriptive method of research was used in this research with two sets of questionnaires used to gather the perceptions of the respondents. The highest rating was given for the strategic value where the building is located for canteen teachers, the safety of the foods for sale and for non-canteen teachers, accessibility of the building to pupils and teachers. Statement of the problem

The study was conducted to make an assessment on the School Canteen Management in Public Secondary High Schools of Zone II, Division of Zambales. Specifically, the study attempted to provide answers to the following questions:

1. What is the profile of the students in terms of:

1.1. Age;

1.2. Sex;

1.3. Grade level;

1.4. Daily allowance;
2. What is the profile of the teachers, parents and canteen operators in terms of:

2.1. Age;

2.2. Sex;

2.3. Civil Status;

2.4. Monthly Income;

2.5. Educational Attainment;

2.6. Religious Affiliation;

2.7. Length of experience in canteen operation; and

2.8. Type of Canteen?

3. How is the school canteen Management in Public Secondary High School in Zone II, Division of Zambales described by teachers, parents and canteen operators as to :

3.1. Permit and clearance;

3.2. Canteen personnel and staff;

3.3. Price of Commodities;

3.4. Food Security and Standard;

3.5. Quality and Quantity of Food served;

3.6. Kinds of Services Rendered to Customers;

3.7. Transparency and Accountability;

3.8. Sharing of Proceeds; and

3.9. Reports and Documents?

4. How is the school canteen Management in Public Secondary High Schools in Zone II, Division of Zambales describe by students as to :

4.1. Permit and clearance;

4.2. Canteen personnel and staff;

4.3. Price of Commodities;

4.4. Food Security and Standard;

4.5. Quality and Quantity of Food served;

4.6. Kinds of Services Rendered to Customers; and

4.7. Transparency and Accountability?

5. Is there a significant difference in the School Canteen Management in Public Secondary High School Students of Zone II, Division of Zambales as described by the teacher, parent and canteen operators when grouped according to profile variables?

6. Is there a significant difference in the School Canteen Management in Public Secondary High School as perceived by the student respondents when grouped according to profile variables?

7. Is there significant relationship between the quality and quantity of the food served and the price and commodities?

\section{SCOPE AND DELIMITATION}

The study focused on the assessment of the management of canteen as perceived by the teachers, parents, school canteen operators and students of Zone II, Division of Zambales. This study was limited to the assessment of the school canteen in terms of management activities, utilization of facilities, quality and quantity of food served, kinds of services rendered and prices of the commodities offered. The study was conducted during the school year 2018-2019.

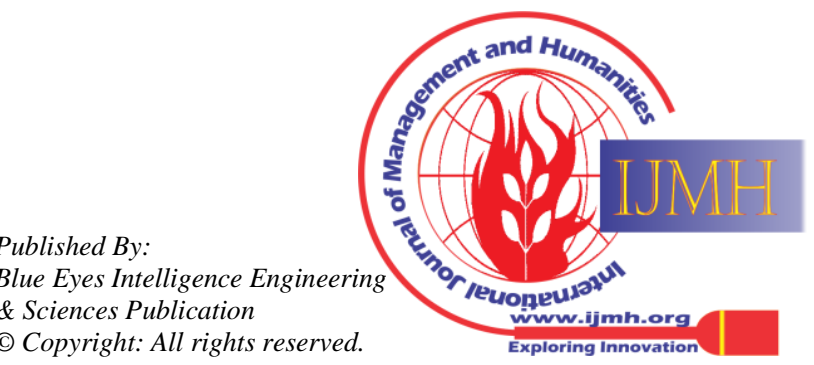


The researcher limited this assessment to the overall performance of the canteen management.

\section{RESEARCH METHODOLOGY}

\section{Research Design}

The researcher used the descriptive method and gathered information through the use of a survey questionnaire as an instrument, to give the respondents more time to provide their answers freely and independently. The descriptive method was used to assess the administration and operations of school canteen of Zone II, Division of Zambales. This research was conducted with the approval of the clientele on the services rendered by the school canteen staff. It gathered the data on the observations of the respondents about how the management handles the daily operations and how they want it to be efficient and maintained so that they continue to uphold its mission and vision.

\section{Population Sample}

The target population of the study includes the students from all year levels, the members of the faculty, parents and canteen operators. To maintain the adequacy and balance of the results of this study, the researcher used the stratified random sampling technique. An equal number of respondents were taken from each stratum of the population. The study was conducted at zone II, Divison of Zambales. It covers the public secondary high schools namely: Zambales National High School, Panan National High School and Locloc National High School. The target population of the study includes the students from all year levels, the members of the faculty, parents and canteen operators. To maintain the adequacy and balance of the results of this study, the researcher used the stratified random sampling technique. An equal number of respondents were taken from each stratum of the population.

\section{Instrumentation}

The researcher formulated the necessary items of the instrument to measure the variables in the study. A Likert Scale type of questionnaire designed to determine the respondent's extent of agreement.

The questionnaire was adopted on the study of Constantino (2019), which was used in her study on Food Court Administration and Operation at NEUST. To improve further the questionnaire, some modifications were made. With this, the researcher then proceeds with the final copies of the questionnaire for distributions among the respondents. It includes: (1) the profile of the teachers, parents and canteen operators (2) profile of the students, (3) the school canteen Management in Public Secondary High School in Zone II, Division of Zambales described by teachers, parents and canteen operators, (4) school canteen Management in Public Secondary High Schools in Zone II, Division of Zambales describe by students, (5) significant difference in the School Canteen Management in Public Secondary High School Students of Zone II, Division of Zambales as described by the teacher, parent and canteen operators when grouped according to profile variables, (6) significant difference in the School Canteen Management in Public Secondary High School as perceived by the student respondents when grouped according to profile, (7) significant relationship between the quality and quantity of the food served and the price and commodities.

\section{Presentation, Analysis, and Interpretation Of Data}

\section{SUMMARY OF FINDINGS}

Analysis of Variance to test differences on the perception of the teachers, parents, and canteen owner's respondents towards school canteen management as to sharing and proceeds when grouped according to profile variables

\begin{tabular}{|c|c|c|c|c|c|c|c|}
\hline Sources of $\mathrm{Va}$ & ariations & SS & df & MS & $\mathbf{F}$ & Sig. & Decision \\
\hline & Between Groups & 2.929 & 5 & 0.586 & 1.234 & 0.298 & Accept Ho \\
\hline Age & Within Groups & 52.710 & 111 & 0.475 & & & Not Significant \\
\hline & Total & 55.640 & 116 & & & & \\
\hline & Between Groups & .899 & 1 & 0.899 & 1.888 & 0.172 & Accept Ho \\
\hline Sex & Within Groups & 54.741 & 115 & 0.476 & & & Not Significant \\
\hline & Total & 55.640 & 116 & & & & \\
\hline & Between Groups & 0.597 & 2 & 0.298 & 0.618 & 0.541 & Accept Ho \\
\hline Civil Status & Within Groups & 55.043 & 114 & 0.483 & & & Not Significant \\
\hline & Total & 55.640 & 116 & & & & \\
\hline & Between Groups & 1.808 & 5 & 0.362 & 0.745 & 0.591 & Accept Ho \\
\hline Family Monthly Income & Within Groups & 53.832 & 111 & 0.485 & & & Not Significant \\
\hline & Total & 55.640 & 116 & & & & \\
\hline & Between Groups & 8.501 & 5 & 1.700 & 4.003 & 0.002 & Reject Ho \\
\hline Hignest Eaucational & Within Groups & 47.139 & 111 & 0.425 & & & Significant \\
\hline & Total & 55.640 & 116 & & & & \\
\hline & Between Groups & 1.658 & 5 & 0.332 & 0.682 & 0.638 & Accept Ho \\
\hline Religion & Within Groups & 53.982 & 111 & 0.486 & & & Not Significant \\
\hline & Total & 55.640 & 116 & & & & \\
\hline & Between Groups & 4.354 & 5 & 0.871 & 1.885 & 0.103 & Accept Ho \\
\hline Lengtn or y ears on & Within Groups & 51.286 & 111 & 0.462 & & & Not Significant \\
\hline & Total & 55.640 & 116 & & & & \\
\hline & Between Groups & 7.633 & 3 & 2.544 & 5.989 & 0.001 & Reject Ho \\
\hline Type of Canteen & Within Groups & 48.006 & 113 & 0.425 & & & Significant \\
\hline & Total & 55.640 & 116 & & & & \\
\hline
\end{tabular}

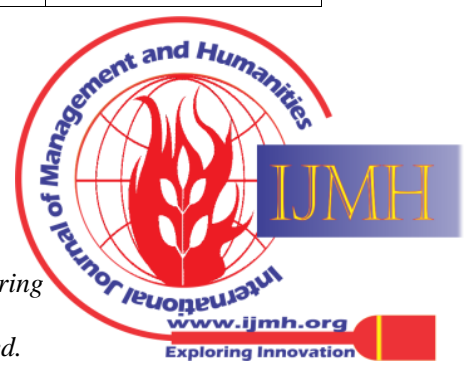


Analysis of Variance to test differences on the perception of the teachers, parents, and canteen owner's respondents towards school canteen management as to Reports and documentation when grouped according to profile variables

\begin{tabular}{|c|c|c|c|c|c|c|c|}
\hline Sources of Va & ariations & SS & df & MS & $\mathbf{F}$ & Sig. & Decision \\
\hline \multirow{3}{*}{ Age } & Between Groups & 4.908 & 5 & 0.982 & 1.934 & 0.094 & Accept Ho \\
\hline & Within Groups & 56.328 & 111 & 0.507 & & & Not Significant \\
\hline & Total & 61.236 & 116 & & & & \\
\hline \multirow{3}{*}{ Sex } & Between Groups & 0.630 & 1 & 0.630 & 1.196 & 0.276 & Accept Ho \\
\hline & Within Groups & 60.605 & 115 & 0.527 & & & Not Significant \\
\hline & Total & 61.236 & 116 & & & & \\
\hline \multirow{3}{*}{ Civil Status } & Between Groups & 0.591 & 2 & 0.296 & 0.556 & 0.575 & Accept Ho \\
\hline & Within Groups & 60.644 & 114 & 0.532 & & & Not Significant \\
\hline & Total & 61.236 & 116 & & & & \\
\hline \multirow{3}{*}{ Family Monthly Income } & Between Groups & 2.651 & 5 & .530 & 1.004 & 0.419 & Accept Ho \\
\hline & Within Groups & 58.585 & 111 & 0.528 & & & Not Significant \\
\hline & Total & 61.236 & 116 & & & & \\
\hline \multirow{3}{*}{$\begin{array}{c}\text { Highest Educational } \\
\text { Attainment }\end{array}$} & Between Groups & 6.009 & 5 & 1.202 & 2.415 & 0.040 & Reject Ho \\
\hline & Within Groups & 55.227 & 111 & 0.498 & & & Significant \\
\hline & Total & 61.236 & 116 & & & & \\
\hline \multirow{3}{*}{ Religion } & Between Groups & 2.142 & 5 & 0.428 & 0.805 & 0.549 & Accept Ho \\
\hline & Within Groups & 59.094 & 111 & 0.532 & & & Not Significant \\
\hline & Total & 61.236 & 116 & & & & \\
\hline \multirow{3}{*}{$\begin{array}{l}\text { Length of Years on } \\
\text { Operation }\end{array}$} & Between Groups & 7.082 & 5 & 1.416 & 2.903 & 0.017 & Reject Ho \\
\hline & Within Groups & 54.154 & 111 & 0.488 & & & Significant \\
\hline & Total & 61.236 & 116 & & & & \\
\hline \multirow{3}{*}{ Type of Canteen } & Between Groups & 9.778 & 3 & 3.259 & 7.158 & 0.000 & Reject Ho \\
\hline & Within Groups & 51.457 & 113 & 0.455 & & & Significant \\
\hline & Total & 61.236 & 116 & & & & \\
\hline
\end{tabular}

Analysis of Variance to test differences on the perception of the student respondents towards school canteen management as to permit and clearance when grouped according to profile variables

\begin{tabular}{|c|l|r|r|r|r|r|c|}
\hline \multicolumn{2}{|c|}{ Sources of Variations } & \multicolumn{1}{c|}{ SS } & \multicolumn{1}{c|}{ df } & \multicolumn{1}{c|}{ MS } & F & Sig. & Decision \\
\hline \multirow{4}{*}{ Age } & Between Groups & 1.741 & 4 & 0.435 & 1.001 & 0.409 & Accept Ho \\
\cline { 2 - 8 } & Within Groups & 59.566 & 137 & 0.435 & & & Not Significant \\
\cline { 2 - 8 } & Total & 61.307 & 141 & & & & \\
\hline \multirow{3}{*}{ Sex } & Between Groups & 4.160 & 1 & 4.160 & 10.191 & 0.002 & Reject Ho \\
\cline { 2 - 8 } & Within Groups & 57.148 & 140 & 0.408 & & & Significant \\
\cline { 2 - 8 } & Total & 61.307 & 141 & & & & \\
\hline \multirow{3}{*}{ Daily Allowance } & Between Groups & 0.590 & 5 & 0.118 & 0.264 & 0.932 & Accept Ho \\
\cline { 2 - 8 } & Within Groups & 60.717 & 136 & 0.446 & & & Not Significant \\
\cline { 2 - 8 } & Total & 61.307 & 141 & & & & \\
\hline \multirow{3}{*}{ Grade Level } & Between Groups & 0.000 & 1 & 0.000 & 0.000 & 0.991 & Accept Ho \\
\cline { 2 - 8 } & Within Groups & 61.307 & 140 & 0.438 & & & Not Significant \\
\cline { 2 - 8 } & Total & 61.307 & 141 & & & & \\
\hline
\end{tabular}

Analysis of Variance to test differences on the perception of the student respondents towards school canteen management as to canteen personnel and staff when grouped according to profile variables

\begin{tabular}{|c|l|r|r|r|r|r|c|}
\hline \multicolumn{2}{|c|}{ Sources of Variations } & \multicolumn{1}{|c|}{ SS } & df & MS & F & Sig. & Decision \\
\hline \multirow{4}{*}{ Age } & Between Groups & 0.548 & 4 & 0.137 & 0.317 & 0.866 & Accept Ho \\
\cline { 2 - 9 } & Within Groups & 59.227 & 137 & 0.432 & & & Not Significant \\
\cline { 2 - 9 } & Total & 59.775 & 141 & & & & \\
\hline \multirow{3}{*}{ Sex } & Between Groups & 6.162 & 1 & 6.162 & 16.090 & 0.000 & Reject Ho \\
\cline { 2 - 9 } & Within Groups & 53.613 & 140 & 0.383 & & & Significant \\
\cline { 2 - 9 } & Ootal & 59.775 & 141 & & & & \\
\hline \multirow{3}{*}{ Daily Allowance } & Between Groups & 0.341 & 5 & 0.068 & 0.156 & 00.978 & Accept Ho \\
\cline { 2 - 8 } & Within Groups & 59.433 & 136 & 0.437 & & & Not Significant \\
\cline { 2 - 8 } & Ootal & 59.775 & 141 & & & & \\
\hline \multirow{3}{*}{ Grade Level } & Between Groups & .675 & 1 & 0.675 & 1.599 & 0.208 & Accept Ho \\
\cline { 2 - 8 } & Within Groups & 59.100 & 140 & 0.422 & & & Not Significant \\
\cline { 2 - 8 } & Total & 59.775 & 141 & & & & \\
\hline
\end{tabular}

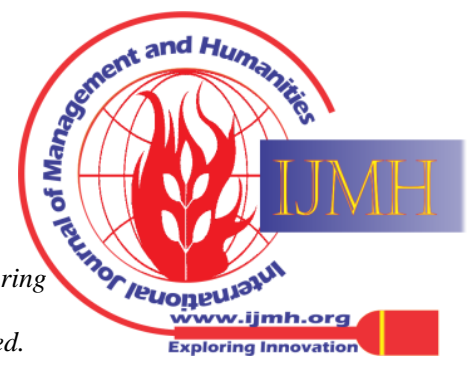


Analysis of Variance to test differences on the perception of the student respondents towards school canteen management as to price and commodities when grouped according to profile variables

\begin{tabular}{|c|c|c|c|c|c|c|c|}
\hline \multicolumn{2}{|c|}{ Sources of Variations } & SS & df & MS & $\mathbf{F}$ & Sig. & Decision \\
\hline \multirow{3}{*}{ Age } & Between Groups & 0.474 & 4 & 0.119 & 0.259 & 0.904 & Accept Ho \\
\hline & Within Groups & 62.776 & 137 & 0.458 & & & Not Significant \\
\hline & Total & 63.250 & 141 & & & & \\
\hline \multirow{3}{*}{ Sex } & Between Groups & 6.055 & 1 & 6.055 & 14.821 & 0.000 & Reject Ho \\
\hline & Within Groups & 57.195 & 140 & 0.409 & & & Significant \\
\hline & Total & 63.250 & 141 & & & & \\
\hline \multirow{3}{*}{ Daily Allowance } & Between Groups & 2.973 & 5 & 0.595 & 1.341 & 0.251 & Accept Ho \\
\hline & Within Groups & 60.277 & 136 & 0.443 & & & Not Significant \\
\hline & Total & 63.250 & 141 & & & & \\
\hline \multirow{3}{*}{ Grade Level } & Between Groups & 0.020 & 1 & 0.020 & 0.043 & 0.835 & Accept Ho \\
\hline & Within Groups & 63.230 & 140 & 0.452 & & & Not Significant \\
\hline & Total & 63.250 & 141 & & & & \\
\hline
\end{tabular}

Analysis of Variance to test differences on the perception of the student respondents towards school canteen

management as to food security and standards when grouped according to profile variables

\begin{tabular}{|c|c|c|c|c|c|c|c|}
\hline Sources of & riations & SS & df & MS & $\mathbf{F}$ & Sig. & Decision \\
\hline \multirow{3}{*}{ Age } & Between Groups & 0.780 & 4 & 0.195 & 0.408 & 0.803 & Accept Ho \\
\hline & Within Groups & 65.405 & 137 & .477 & & & Not Significant \\
\hline & Total & 66.185 & 141 & & & & \\
\hline \multirow{3}{*}{ Sex } & Between Groups & 2.717 & 1 & 2.717 & 5.992 & 0.016 & Reject Ho \\
\hline & Within Groups & 63.468 & 140 & 0.453 & & & Significant \\
\hline & Total & 66.185 & 141 & & & & \\
\hline \multirow{3}{*}{ Daily Allowance } & Between Groups & 0.629 & 5 & 0.126 & 0.261 & 0.934 & Accept Ho \\
\hline & Within Groups & 65.556 & 136 & 0.482 & & & Not Significant \\
\hline & Total & 66.185 & 141 & & & & \\
\hline \multirow{3}{*}{ Grade Level } & Between Groups & 0.310 & 1 & 0.310 & 0.659 & 0.418 & Accept Ho \\
\hline & Within Groups & 65.875 & 140 & 0.471 & & & Not Significant \\
\hline & Total & 66.185 & 141 & & & & \\
\hline
\end{tabular}

Analysis of Variance to test differences on the perception of the student respondents towards school canteen management as to quality and quantity of food served when grouped according to profile variables

\begin{tabular}{|c|c|c|c|c|c|c|c|}
\hline Sources of & ariations & SS & df & MS & $\mathbf{F}$ & Sig. & Decision \\
\hline \multirow{3}{*}{ Age } & Between Groups & 1.277 & 4 & 0.319 & 0.649 & 0.629 & Accept Ho \\
\hline & Within Groups & 67.381 & 137 & 0.492 & & & Not Significant \\
\hline & Total & 68.657 & 141 & & & & \\
\hline \multirow{3}{*}{ Sex } & Between Groups & 11.187 & 1 & 11.187 & 27.252 & 0.000 & Reject Ho \\
\hline & Within Groups & 57.470 & 140 & 0.411 & & & Significant \\
\hline & Total & 68.657 & 141 & & & & \\
\hline \multirow{3}{*}{ Daily Allowance } & Between Groups & 0.404 & 5 & 0.081 & 0.161 & 0.976 & Accept Ho \\
\hline & Within Groups & 68.253 & 136 & 0.502 & & & Not Significant \\
\hline & Total & 68.657 & 141 & & & & \\
\hline \multirow{3}{*}{ Grade Level } & Between Groups & 0.183 & 1 & 0.183 & 0.374 & 0.542 & Accept Ho \\
\hline & Within Groups & 68.474 & 140 & 0.489 & & & Not Significant \\
\hline & Total & 68.657 & 141 & & & & \\
\hline
\end{tabular}

Analysis of Variance to test differences on the perception of the student respondents towards school canteen management as to kinds of services rendered to the customers when grouped according to profile variables

\begin{tabular}{|c|c|c|c|c|c|c|c|}
\hline \multicolumn{2}{|c|}{ Sources of Variations } & SS & df & MS & $\mathbf{F}$ & Sig. & Decision \\
\hline \multirow{3}{*}{ Age } & Between Groups & 1.027 & 4 & 0.257 & 0.539 & 0.707 & Accept Ho \\
\hline & Within Groups & 65.250 & 137 & 0.476 & & & Not Significant \\
\hline & Total & 66.277 & 141 & & & & \\
\hline \multirow{3}{*}{ Sex } & Between Groups & 6.335 & 1 & 6.335 & 14.797 & 0.000 & Reject Ho \\
\hline & Within Groups & 59.942 & 140 & 0.428 & & & Significant \\
\hline & Total & 66.277 & 141 & & & & \\
\hline \multirow{3}{*}{ Daily Allowance } & Between Groups & 1.042 & 5 & 0.208 & 0.434 & 0.824 & Accept Ho \\
\hline & Within Groups & 65.235 & 136 & 0.480 & & & Not Significant \\
\hline & Total & 66.277 & 141 & & & & \\
\hline \multirow{3}{*}{ Grade Level } & Between Groups & 0.250 & 1 & 0.250 & 0.531 & 0.467 & Accept Ho \\
\hline & Within Groups & 66.027 & 140 & 0.472 & & & Not Significant \\
\hline & Total & 66.277 & 141 & & & & \\
\hline
\end{tabular}

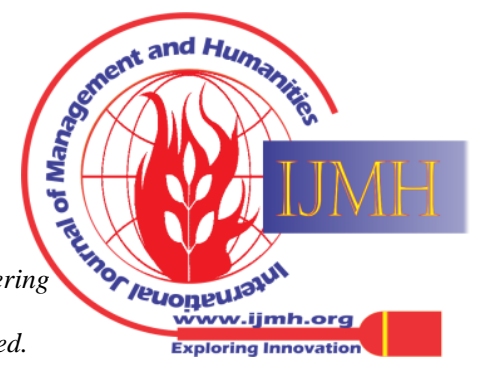


Analysis of Variance to test differences on the perception of the student respondents towards school canteen management as to transparency and accountability when grouped according to profile variables

\begin{tabular}{|c|c|c|c|c|c|c|c|}
\hline Sources of & ariations & SS & df & MS & $\mathbf{F}$ & Sig. & Decision \\
\hline \multirow{3}{*}{ Age } & Between Groups & 0.598 & 4 & 0.149 & 0.322 & 0.863 & Accept Ho \\
\hline & Within Groups & 63.544 & 137 & 0.464 & & & Not Significant \\
\hline & Total & 64.142 & 141 & & & & \\
\hline \multirow{3}{*}{ Sex } & Between Groups & 3.396 & 1 & 3.396 & 7.827 & 0.006 & Reject Ho \\
\hline & Within Groups & 60.746 & 140 & 0.434 & & & Significant \\
\hline & Total & 64.142 & 141 & & & & \\
\hline \multirow{3}{*}{ Daily Allowance } & Between Groups & 0.401 & 5 & 0.080 & 0.171 & 0.973 & Accept Ho \\
\hline & Within Groups & 63.741 & 136 & 0.469 & & & Not Significant \\
\hline & Total & 64.142 & 141 & & & & \\
\hline \multirow{3}{*}{ Grade Level } & Between Groups & 0.278 & 1 & 0.278 & 0.609 & 0.437 & Accept Ho \\
\hline & Within Groups & 63.864 & 140 & 0.456 & & & Not Significant \\
\hline & Total & 64.142 & 141 & & & & \\
\hline
\end{tabular}

Pearson Product Moment Coefficient of Correlation to test relationship between the price and quality and quality food served

\begin{tabular}{|c|l|r|r|}
\hline \multicolumn{2}{|c|}{ Sources of Classification } & Price & \multicolumn{1}{c|}{$\begin{array}{c}\text { Quality and } \\
\text { Quantity }\end{array}$} \\
\hline \multirow{4}{*}{$\begin{array}{c}\text { Teachers, Parents, and } \\
\text { Canteen Owners }\end{array}$} & Pearson Correlation & & $0.530^{* *}$ \\
\cline { 2 - 4 } Student & Sig. (2-tailed) & 117 & 0 \\
\cline { 2 - 4 } & $\mathrm{N}$ & $0.664^{* *}$ & 117 \\
\cline { 2 - 4 } & Pearson Correlation & 0 & 142 \\
\cline { 2 - 4 } & Sig. (2-tailed) & 142 & \\
\cline { 2 - 4 } & $\mathrm{N}$ & & \\
\hline \multirow{4}{*}{$* *$. Correlation is significant at the 0.01 level (2-tailed). }
\end{tabular}

1. Profile of the Teachers, Parents, and Canteen Owners - Respondents

1.1. Age. There were 26 or $22.20 \%$, from age group of 46 years old and above; 37 or $31.60 \%, 41-45$ years old; 29 or $24.80 \%$, 36-40 years old; 8 or $6.80 \%$, 31-35 years old; 5 or $4.30 \%$, 26-30 years old and 12 or $10.30 \%$, from age group of $21-25$ years old. The computed mean age of the respondents was $39.50 \%$ years old.

1.2. Sex. Majority with 95 or equivalent to $81.20 \%$, are females and 22 or $18.80 \%$ are males.

1.3. Civil Status. Majority with 80 or $68.40 \%$ are married; 32 or $27.40 \%$, single and 5 or $4.30 \%$ are separated.

1.4. Family Monthly Income. Majority with 82 or equivalent to 70.10 with family income of 24,000 and below; 4 or $3.40 \%$, from 46,000 and above; 5 or $4.30 \%, 40,000-45,000$; 1 or $0.90 \%, 35,000-$ 40,000 ; 7 or $6.00 \%, 30,000-35,000$; and 18 or $15.40 \%$ with family income of 25,000-30,000.

1.5. Highest Educational Attainment. Mostly with 44 or $37.60 \%$ are high school graduate; 43 or $36.80 \%$ are BS degree or college graduate; 20 or 17.105, BS degree with MA units; 6 or $5.10 \%$, Masteral degree holders; 1 or $0.90 \%$, MA with Doctoral degree; and 3 or $2.60 \%$, are Doctoral degree holders.

1.6. Religion. Majority with 82 or equivalent to $70.10 \%$ are Roman Catholic; 15 or $12.80 \%$, Iglesia ni Cristo; 3 or $2.60 \%$ are Baptist; 14 or $12.00 \%$, Born Again; 1 or $0.90 \%$ is a Mormon; and 2 or 1.705 are Protestants.
1.7. Length of Years on Canteen Operation. Majority with 75 or equivalent to 64.10 are teachers who are parents and are not operating the canteen; 2 or $1.70 \%$ with $16-20$ years of operating canteen; 5 or $4.30 \%, 11-15$ years; 1 or $0.90 \%$, 610 years of operation; 11 or 9.40 , with $3-5$ years of operation and 23 or $19.70 \%$ with 1 -2 years of canteen operation.

1.8. Types of Canteen Operation. Mostly with 38 or 32.50 where the canteen is managed by a TLE teachers; 44 or $37.60 \%$, the canteen is a cooperative type run by teachers and personnel who are members of the school cooperative; 14 or $12.00 \%$, the canteen is managed by the administrator of the school; and 21 or $17.90 \%$, the canteen is operated by a private concessioner.

\section{Profile of the Student Respondents}

2.1. Sex. Majority with 98 or equivalent to $69.00 \%$ are males and 44 or $31.00 \%$ are females.

2.2. Age. Majority with 99 or $39.72 \%$ are from age group of 16-17 years old; 3 or 2.11, 22 years old and above; 5 or $3.52 \%$ are from $20-21$ years old and 35 or $24.65 \%$, from $18-19$ years old. The computed mean age of the respondents was 17.30 years old.

2.3. Grade Level. Majority with 79 or $55.60 \%$ are from Grade 11 while 63 or $44.40 \%$ from Grade 12.

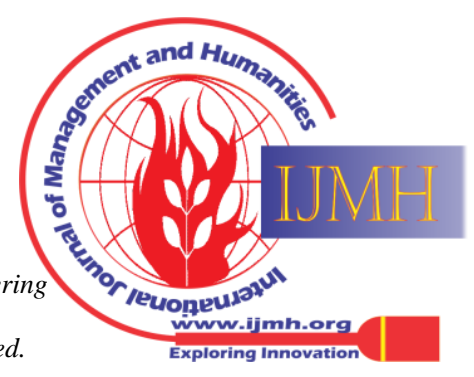


2.4. Daily Allowance. Mostly with 32 or $22.50 \%$ with daily allowance of Php101.00-150.00; 4 or 2.805, Php301.00 and above; 1 or $0.70 \%$, Php251.00-300.00; 7 or 4.90\%, Php151.00200.00; and 2 or $1.40 \%$ with daily allowance of Php201.00-250.00 daily.

3. Perception Teachers, Parents, and Canteen Owners Respondents towards School Canteen Management

3.1. Permit and Clearance. The respondents assessed "evident" on indicator where the canteen pay the necessary bills payment for permission to operate, like electricity, water, salaries of personnel and staff, with mean of 3.11 and ranked $1^{\text {st }}$ while least on indicator, the canteen staff and operators seek medical examination from a medical doctor, 2.58 and ranked $5^{\text {th }}$. The computed overall weighted mean on the responses towards permit and clearance was 2.86 with qualitative interpretation of "evident".

3.2. Canteen Personnel and Staff. The respondents assessed "evident" on indicator where canteen personnel and staff wear clean and proper attire white shirt, blouse, colored pants with hairnet, apron and appropriate footwear manifested on the weighted mean value of 2.84 and ranked $1^{\text {st }}$ while least on indicator where canteen personnel and staff wear identification card with photo while inside the premises of the canteen, with mean of 2.38 and ranked $5^{\text {th }}$. The computed overall weighted mean on the responses towards canteen personnel and staff was 2.63 with qualitative interpretation of "evident".

3.3. Price and Commodities. The respondents assessed "evident" on indicator where healthy canteen choices are sold at competitive prices manifested on the weighted mean value of 2.85 and ranked $1^{\text {st }}$ while least on indicator where canteen offers cost saving meals to the customers as in value or combo meal, with mean of 2.75 and ranked $5^{\text {th }}$. The computed overall weighted mean on the responses towards price of commodities was 2.63 with qualitative interpretation of "evident".

3.4. Food Security and Standard. The respondents assessed "evident" on indicator where canteen uses equipment, utensils, facilities, furniture and other supplies in canteen operators manifested on the weighted mean value of 3.03 and ranked $1^{\text {st }}$ while least on indicator where canteen regulates the use of magic sarap and other monosodium glutamate, with mean of 2.69 and ranked $5^{\text {th }}$. The computed overall weighted mean on the responses towards price of commodities was 2.91 with qualitative interpretation of "evident".

3.5. Quality and Quantity of food Served. The respondents assessed "evident" on indicator where canteen serves foods that are fresh, newly cooked or prepared manifested on the weighted mean value of 3.06 and ranked $1^{\text {st }}$ while least on indicator where canteen staff members undertake food safety training to ensure quality and maintain food safety, with mean of 2.79 and ranked $5^{\text {th }}$. The computed overall weighted mean on the responses towards quality and quantity of food served was 2.91 with qualitative interpretation of "evident".

3.6. Kinds of Services Rendered to Customers. The respondents assessed "evident" on indicator where payments are properly and accurately changed and counted manifested on the weighted mean value of 3.01 and ranked $1^{\text {st }}$ while least on indicator where ventilation and lightning facilities to make the diners comfortable are provided, with mean of 2.75 and ranked $5^{\text {th }}$. The computed overall weighted mean on the responses towards kinds of services rendered to customers was 2.94 with qualitative interpretation of "evident".

3.7. Transparency and Accountability. The respondents assessed "evident" on indicator where canteen has an organize school level auditing composed of the member faculty, president head, TLE , Math department manifested on the weighted mean value of 2.92 and ranked $1^{\text {st }}$ while least on indicator where statement of receipts and disbursements are presented by transparency, with mean of 2.70 and ranked $5^{\text {th }}$. The computed overall weighted mean on the responses towards transparency and accountability was 2.77 with qualitative interpretation of "evident".

3.8. Canteen Sharing. The respondents assessed "evident" on indicator where canteen spend 35\% of the income for feeding program manifested on the weighted mean value of 2.72 and ranked $1^{\text {st }}$ while least on indicator where the A.E. Instructional Fund of $10 \%$, with mean of 2.60 and ranked $10^{\text {th }}$. The computed overall weighted mean on the responses towards canteen sharing was 2.66 with qualitative interpretation of "evident".

3.9. Reports and Documents. The respondents assessed "evident" on indicator where the financial statements and Expenses is presented for proper auditing manifested on the weighted mean value of 2.79 and ranked $1^{\text {st }}$ while least on indicator where the Statement of Cash Flows is presented for proper auditing with mean of 2.62 and ranked $5^{\text {th }}$. The computed overall weighted mean on the responses towards reports and documents was 2.71 with qualitative interpretation of "evident".

4. Perception of the Student Respondents School Canteen Management

4.1. Permit and Clearance. The respondents assessed "evident" on indicator where the canteen has a sanitary permit from the local government health and sanitation unit manifested on the weighted mean value of 2.87 and ranked $1^{\text {st }}$ while least on indicator where the canteen staff and operators seek medical examination from a medical doctor with mean of 2.44 and ranked $5^{\text {th }}$.

Published By:

Blue Eyes Intelligence Engineerin \& Sciences Publication 
The computed overall weighted mean on the responses towards permit and clearance was 2.73 with qualitative interpretation of "evident".

4.2. Canteen Personnel and Staff. The respondents assessed "evident" on indicator where the canteen personnel and staff wear clean and proper attire white shirt, blouse, colored pants with hairnet, apron and appropriate footwear manifested on the weighted mean value of 2.75 and ranked $1^{\text {st }}$ while least on indicator where the canteen staff and operators wear identification card with photo mean of 2.66 and ranked $5^{\text {th }}$. The computed overall weighted mean on the responses towards canteen personnel and staff was 2.73 with qualitative interpretation of "evident".

4.3. Price and Commodities. The respondents assessed "evident" on indicator where variation in prices of food depends on quality and quantity manifested on the weighted mean value of 2.84 and ranked $1^{\text {st }}$ while least on indicator where the canteen offers cost saving meals to the customers as in value or combo meal with mean of 2.39 and ranked $5^{\text {th }}$. The computed overall weighted mean on the responses towards price of commodities was 2.69 with qualitative interpretation of "evident".

4.4. Food Security and Standard. The respondents assessed "evident" on indicator where canteen uses covers and containers for safekeeping manifested on the weighted mean value of 2.89 and ranked $1^{\text {st }}$ while least on indicator where the canteen regulates the use of magic sarap and other monosodium glutamate with mean of 2.60 and ranked $5^{\text {th }}$. The computed overall weighted mean on the responses towards food security and standards was 2.78 with qualitative interpretation of "evident".

4.5. Quality and Quantity of Food served. The respondents assessed "evident" on indicator where canteen serves foods that are fresh, newly cooked or prepared manifested on the weighted mean value of 2.93 and ranked $1^{\text {st }}$ while least on indicator where the canteen staff members undertake food safety training to ensure quality and maintain food safety with mean of 2.69 and ranked $5^{\text {th }}$. The computed overall weighted mean on the responses towards quality and quantity of food served was 2.79 with qualitative interpretation of "evident".

4.6. Kinds of Services Rendered to Customers. The respondents assessed "evident" on indicator where safety and good quality of equipment and facilities are maintained manifested on the weighted mean value of 2.84 and ranked $1^{\text {st }}$ while least on indicator where the suggestions and easily manage complaints are entertained with mean of 2.54 and ranked $5^{\text {th }}$. The computed overall weighted mean on the responses towards kinds of service rendered to customers was 2.69 with qualitative interpretation of "evident".

4.7. Transparency and Accountability. The respondents assessed "evident" on indicator where canteen has an organize school level while inside the premises of the canteen with

auditing composed of the member faculty, president head, TLE , Math department manifested on the weighted mean value of 2.75 and ranked $1^{\text {st }}$ while least on indicator where the schedule of school share program received from canteen are properly documented with mean of 2.50 and ranked $5^{\text {th }}$. The computed overall weighted mean on the responses towards transparency and accountability was 2.61 with qualitative interpretation of "evident".

5. Test of Differences on the perception of the teachers, parents, and canteen owners respondents towards school canteen management.

5.1. Permit and Clearance. There is no significant difference when grouped according to age, sex, civil status, family monthly income, highest educational attainment, and religion manifested on the computed P-value of 0.729, 0.739, 0.686, $0.503,0.484,0.253$, and .0381 which all are higher than 0.05 Alpha Level of Significance, hence the Null Hypothesis is Accepted. On the other hand, there is significant difference when grouped according to type of canteen operation manifested on the P-value of 0.000 which is lower than $(<) 0.05$ Alpha Level of Significance, hence the Null Hypothesis is Rejected.

5.2. Canteen Personnel and Staff. There is no significant difference when grouped according to age, sex, civil status, family monthly income, highest educational attainment, religion, and length of years of operation manifested on the computed P-value of 0.465, 0.428, 0.868, 0.175, 0.278 , and 0.960 which are higher than $(>) 0.05$ Alpha Level of Significance, hence the Null Hypothesis is Accepted. On the other hand, there is significant difference when grouped according to length of years of operation and type of canteen operation manifested on the P-value of 0.043 and 0.001 which are lower than $(<) 0.05$ Alpha Level of Significance, hence the Null Hypothesis is Rejected.

5.3. Price and Commodities. There is no significant difference when grouped according to sex, civil status, family monthly income, highest educational attainment, and religion manifested on the computed P-value of 0.744, 0.080, 0.161, 0.295 , and 0.940 which are higher than $(>) 0.05$ Alpha Level of Significance, hence the Null Hypothesis is Accepted. On the other hand, there is significant difference when grouped according to age, length of years of operation and type of canteen operation manifested on the P-value of $0.015,0.022$ and 0.001 which are lower than $(<)$ 0.05 Alpha Level of Significance, hence the Null Hypothesis is Rejected. 
5.4. Food Security and Standard. There is no significant difference when grouped according to age, sex, civil status, family monthly income, highest educational attainment, religion and length of years of operation manifested on the computed P-value of $0.219,0.843,0.412,0.335$, $0.556,0.354$ and 0.059 which are higher than $(>)$ 0.05 Alpha Level of Significance, hence the Null is significant difference when grouped according to type of canteen operation manifested on the Pvalue of 0.010 which is lower than $(<) 0.05$ Alpha Level of Significance, hence the Null Hypothesis is Rejected.

5.5. Quality and Quantity of Food Served. There is no significant difference when grouped according to age, sex, civil status, family monthly income, highest educational attainment, and religion manifested on the computed P-value of 0.340 , $0.341,0.963,0.907,0.269$, and 0.166 which are higher than (>) 0.05 Alpha Level of Significance, hence the Null Hypothesis is Accepted. On the other hand, there is significant difference when grouped according to length of years of operation and type of canteen operation manifested on the P-value of 0.023 and 0.013 which are lower than $(<) 0.05$ Alpha Level of Significance, hence the Null Hypothesis is Rejected.

5.6. Kinds of Services rendered to the Customer. There is no significant difference when grouped according to age, sex, civil status, family monthly income, highest educational attainment, and religion manifested on the computed P-value of $0.096,0.639,0.829,0.909,0.325$, and 0.271 which are higher than $(>)$ 0.05 Alpha Level of Significance, hence the Null Hypothesis is Accepted. On the other hand, there is significant years of operation and type of canteen operation manifested on the P-value of 0.009 and 0.006 which are lower than $(<) 0.05$ Alpha Level of Significance, hence the Null Hypothesis is Rejected.

5.7. Transparency and Accountability. There is no significant difference when grouped according to age, sex, civil status, family monthly income, highest educational attainment, and religion manifested on the computed P-value of 0.121 , $0.601,0.714,0.796,0.683$ and 0.100 which are higher than (>) 0.05 Alpha Level of Significance, hence the Null Hypothesis is Accepted. On the other hand, there is significant difference when grouped according to length of years of operation and type of canteen operation manifested on the P-value of 0.034 and 0.000 which are lower than $(<) 0.05$ Alpha Level of Significance, hence the Null Hypothesis is Rejected.

5.8. Sharing and Proceeds. There is no significant difference when grouped according to age, sex, civil status, family monthly income, religion and length of years of operation manifested on the computed P-value of 0.298, 0.172, 0.541, 0.591, and 0.638 which are higher than (>) 0.05 Alpha Level of Significance, hence the Null Hypothesis Hypothesis is Accepted. On the other hand, there difference when grouped according to length of

is Accepted. On the other hand, there is significant difference when grouped according to highest educational attainment and type of canteen operation manifested on the P-value of 0.002 and 0.001 which are lower than $(<) 0.05$ Alpha Level of Significance, hence the Null Hypothesis is Rejected.

5.9. Reports and Documentation. There is no significant difference when grouped according to age, sex, civil status, family monthly income, religion and length of years of operation manifested on the computed P-value of 0.094, $0.276,0.575,0.419$ and 0.549 which are higher than (>) 0.05 Alpha Level of Significance, hence the Null Hypothesis is Accepted. On the other hand, there is significant difference when grouped according to highest educational attainment, length of years of operation and type of canteen operation manifested on the P-value of 0.040 , 0.017 and 0.000 which are lower than $(<) 0.05$ Alpha Level of Significance, hence the Null Hypothesis is Rejected.

6. Test of Differences on the perception of the student respondents towards school canteen management.

6.1. Permit and Clearance. There is no significant difference when grouped according to age, daily allowance and grade level manifested on the computed P-value of $0.409,0.932$ and 0.991 which are higher than (>) 0.05 Alpha Level of Significance, hence the Null Hypothesis is Accepted. On the other hand, there is significant difference when grouped according to sex manifested on the P-value of 0.002 which is lower than $(<) 0.05$ Alpha Level of Significance, hence the Null Hypothesis is Rejected.

6.2. Canteen Personnel and Staff. There is no significant difference when grouped according to age, daily allowance and grade level manifested on the computed P-value of 0.866, 0.978 and 0.208 which are higher than (>) 0.05 Alpha Level of Significance, hence the Null Hypothesis is Accepted. On the other hand, there is significant difference when grouped according to sex manifested on the P-value of 0.000 which is lower than $(<) 0.05$ Alpha Level of Significance, hence the Null Hypothesis is Rejected.

6.3. Price and Commodities. There is no significant difference when grouped according to age, daily allowance and grade level manifested on the computed P-value of $0.904,0.251$, and 0.835 which are higher than (>) 0.05 Alpha Level of Significance, hence the Null Hypothesis is Accepted. On the other hand, there is significant difference when grouped according to sex manifested on the P-value of 0.000 which is lower than $(<) 0.05$ Alpha Level of Significance, hence the Null Hypothesis is Rejected.
Blue Eyes Intelligence Engineering \& Sciences Publication (C) Copyright: All rights reserved.

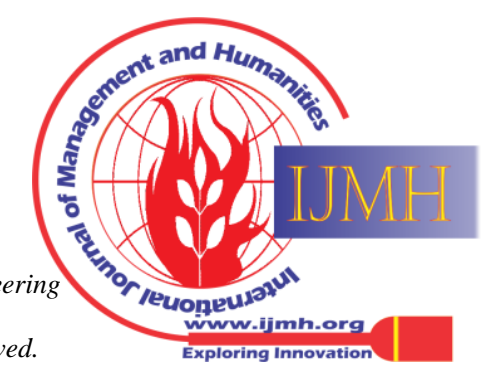


6.4. Food Security and Standard. There is no significant difference when grouped according to age, daily allowance and grade level manifested on the computed P-value of 0.803, 0.934 and 0.418 which are higher than (>) 0.05 Alpha Level of Significance, hence the Null Hypothesis is Accepted. On the other hand, there is significant difference when grouped according to sex manifested on the P-value of 0.016 which is lower than $(<) 0.05$ Alpha Level of Significance, hence the Null Hypothesis is Rejected.

6.5. Quality and Quantity of Food Served. There is no significant difference when grouped according to age, daily allowance and grade level manifested on the computed P-value of 0.629 , 0.976 and 0.542 which are higher than $(>) 0.05$ Alpha Level of Significance, hence the Null Hypothesis is Accepted. On the other hand, there is significant difference when grouped according to sex manifested on the P-value of 0.000 which is lower than $(<) \quad 0.05$ Alpha Level of Significance, hence the Null Hypothesis is Rejected.

6.6. Kinds of services rendered to the customer. There is no significant difference when grouped according to age, daily allowance and grade level manifested on the computed P-value of 0.6707 , 0.824 and 0.467 which are higher than (>) 0.05 Alpha Level of Significance, hence the Null Hypothesis is Accepted. On the other hand, there is significant difference when grouped according to sex manifested on the P-value of 0.000 which is lower than $(<) \quad 0.05$ Alpha Level of Significance, hence the Null Hypothesis is Rejected.

6.7. Transparency and Accountability. There is no significant difference when grouped according to age, daily allowance and grade level manifested on the computed P-value of $0.863,0.973$ and 0.437 which are higher than (>) 0.05 Alpha Level of Significance, hence the Null Hypothesis is Accepted. On the other hand, there is significant difference when grouped according to sex manifested on the P-value of 0.006 which is lower than $(<) 0.05$ Alpha Level of Significance, hence the Null Hypothesis is Rejected.

7. Test of Relationship. On the assessment of teachers, parents, and canteen owners, there is moderate relationship between price and quality and quantity food served manifested in the computed Pearson $r$ value of $0.530 * *$. The computed P-value of 0.000 which is lower than $(<)$ 0.05 Alpha level of significance, therefore the Null Hypothesis is rejected, there is significant relationship. On the other hand, the assessment of student respondents, there is moderate relationship between price and quality and quantity food served manifested in the computed Pearson $\mathrm{r}$ value of $0.664 * *$. The computed P-value of 0.000 which is lower than $(<) 0.05$ Alpha level of significance, therefore the Null Hypothesis is rejected, there is significant relationship.

\section{CONCLUSIONS}

Based on the summary of the investigations conducted, the researcher have concluded that:

1. Most of the teachers, parents and canteen owners are adults; female and married. Their monthly family income is meager. Generally they finished high school but majority of them have their BS degree with masteral units and doctorate degree. They belong to Roman Catholics as to their religious affiliation. The canteen owners and teachers have a enough number of experience in the operation of canteen.

2. The student-respondent is a young male, a teenager in Grade 11 and have small amount of money for school daily allowance.

3. The canteen operators assessed that on permit and clearance, personnel and staff, price and commodities, food security and standards, quality and quantity of food served, kinds of service render to the customer, transparency and accountability, sharing and proceeds and reports and documentation are evident.

4. The student respondents assessed in the canteen operation that permit and clearance, personnel and staff, price and commodities, food security and standards, quality and quantity of food served, kinds of service render to the customer, transparency and accountability are evident.

5. There is significant difference when grouped according to length of years of operation and type of canteen operation towards canteen personnel and staff, quality and quantity of food serve, kinds of services rendered to the customers, transparency and accountability; significant on type of canteen towards permit and clearance; significant to age , length of years and type of canteen operation towards price and commodities; significant on highest educational attainment and type of canteen operation towards sharing and proceeds; and significant to highest educational attainment, length of years in the canteen operation and type of canteen operation towards report and documentation.

6. There is significant difference when grouped according to sex on the assessment towards dimension of canteen management as to permit and clearance, personnel and staff, price and commodities, food security and standards, quality and quantity of food served, kinds of service render to the customer, transparency and accountability.

7. There is moderate relationship between prices and commodities and the quality and quantity of food served.

\section{RECOMMENDATIONS}

Based on salient findings and conclusions arrived, the researcher offers the following recommendations:

Blue Eyes Intelligence Engineering \& Sciences Publication 
1. That the school heads should prepare a workable and viable long range master plan on canteen operations and personnel functions.

2. The conduct a regular check-up or ocular visits on school canteens particularly on the kitchen area to assure sanitation and cleanliness in food handling is strongly encouraged.

3. Be ready to entertain and provide immediate action on complaints against mishandling of food and other concerns related to canteen operation

5. Personnel in-charge in cooking should look for organic alternatives of seasoning rather than the use so much amount of glutamate monosodium which affects health and safety condition of the students.

6. Canteen operators/school management should provide continuous training for crews and staff particularly those newly hired to assure safety on food handling and preparation.

7. Future researchers may conduct a similar or parallel study with in-depth and wider in scope so as to validate the findings obtained in the study.

\section{Policy Note \\ School Canteen Management in Public Secondary High Schools of Zone Ii, Division of Zambales}

NOTE: This study focused on the status of existing practices of canteen management in the public secondary high school of Zone II, Division of Zambales as perceived by teachers, students and canteen operators.

\section{REFERENCES}

1. Aleta, J.B. (2002). "Failure Associated with Academic Performance of Students in Science and Technology: The Case of the Negros Oriental Secondary School." Doctoral Dissertation, CLSU, Muñoz Nueva Ecija.

2. Arnold, C. G. (2000). Food practices and nutrition knowledge after graduation for the Expanded Food and Nutrition Education Program (EFNEP). Journal of nutrition education. 2000/05//;32:130-8

3. Azanha, J.M.P. (1995). Comentarios sobre a formacoa de professors em Sao Paulo. In: Educacaao: temas polemicos. Sao Paulo: Martins Fontes

4. Bonoy, R.C. Canteen Management in Mankayan District, Benguet, Division. Unpublished Master's thesis, Baguio. Central University, 1995

5. Brauw, A., Meenakshi, J., \& Gilligan, D. (2012). Introduction of beta-carotene-rich orange sweet potato in rural Uganda resulted in increased Vitamin A intakes among children and women and improved vitamin A status among children. Journal of Nutrition, 142 (6): 1871-1880

6. Bray, R., Gooskens, I., Khan, L., Moses, S., \& Seekings, J. (2010). Growing up in the new South Africa: Childhood and adolescence in post-apatheid. Cape Town: HSRC Press.

7. Cabral, E. \& Sawaya, S. M. (2011). Concepcoes e atuacao professional frente as queixas escolares: Os psicologos dos servicos publicos de saude. Estudos de psicologia, Natal, v. 6, n.2, p. 143-155

8. Chinyoka, K. \& Naidu, N. (2013). Encaging the Caged: Exploring the Impact of Poverty on the Academic Performance of Form Three Learners in Zimbabwe. International Journal of Educational Sciences, 6:203-213

9. Connell, RW. (2010). Poverty and Education. Harvard and Educational Review. 64: 125-150

10. Constantino, Jeanine M. (2019) Food Court Administration and Operation at Nueva Ecija University of Science and Technology: An Assessment. Cabanatuan City

11. Cronin, J. \& Taylor, S. (1992) Measuring service quality: A reexamination and extension. Journal of Marketing, v.56, n. 3, 55-68

12. De Guzman, F. (1992) Food Service Management. Anvil publishing.

13. Dizon, E. (2000) Management Practices of School Canteen in the District of Dinalupihan and their Implications to the Nutritional
4. Provide discounts, combo meals at cheaper price.

Needs of the Pupils. Unpublished Master's Thesis, Virgen Delos Remedios College, March 2000

14. Downie, N., \& Heath, R. (1983) Basic Statistical Methods. The University of Michigan. Harper \& Row.

15. Duncan, DJ., Yeung, JW., Brooks-Gunn, J. \& Smith, JR. (2008). How much does child poverty affect the life chances of children? American Sociological review, 63 (4): 406-423

16. Ecker, O. \& Nene, M. (2012). Nutrition policies in developing countries: Challenges and highlights. Policy Note 1. Washington DC. International Food Policy research Institute.

17. Eclarino, A. (2000). "Determinants of Quality Performance of Grade Pupils in the District of Candelaria, Division of Zambales". Master's Thesis, Columban College, Olongapo City

18. Fanzo, J. (2012). The Nutrition challenge in Sub-Saharan Africa. Human development Report: UNDP

19. Ferguson, CJ., Muñoz, ME., \& Medrano, M.R. (2012). Advertising influences on young children's food choices are only marginally reduced by parental influence: A randomized controlled experiment. Journal of Pediatrics, 160(3): 452-455.

20. Garmo, Mary C. The School Cafeteria. New york, Appleton-Century Crafts Inc. 1978

21. Gay, A. N. (2002). Educational Research Studies. Nairobi MC Millan Press

22. Guzman, Inez de. Food Service and Management. Manila: Saint Berradilla Publication Inc. 1992

23. Hibaya, C. T. (1995). "Academic Performance of Students in Araling Panlipunan of Central Luzon State University Laboratory High School and in Selected Newly Nationalized High School in the Third Congressional District of Nueva Ecija". Master's Thesis, CLSU, Muñoz Nueva Ecija

24. Hinkle, M. (1982) A Mixed Message: The School Vending Machine Journal of School Health. Volume 52, Issue

25. Hochbaum, G. (1981) Theory in Health Education Practice. Health Education \& Behavior. Sage Journals.

26. Jain, S \& Gupta, G. (2004) Measuring Service Quality: Servqual vs Servperf Scales Vikalpa: The Journal for Decision Makers.

27. Jatayna, Teresita M. An Assessment of the Privatization of the school Canteen of San Pedro Relocation Center National High School: Input for Food and Nutrition Policy Formulation. San Pedro, Laguna

28. Jindaratana Porn Orawan. Canteen Management in the Public Elementary Schools Tarlac West District: an Evaluation Unpublished Master's Thesis, Harvadian Colleges, May 1999

29. Johannes, M. (2013) retrieved from school canteen operations and management. www.pressreader.com

30. Kathori, C. (2004) Research Methodology: Methods \& techniques, New Age International Publishers, Second Revised edition, New Delhi.

31. Khan, F. J. \& Khan, C.J. (2005). Motivation: Theory and Research in M.K. 1983, Human Stress and Stressors, Cosmo Publication, New Delhi.

32. Kim, Yen-Soon; Moreo, Patrick; Yeh, Ronnie. (2004) Customers Satisfaction factors Regarding University Food Court Service. Journal of Foodservice Business Research.

33. Kothari, C. R. (2004). Research Methodology Methods and Techniques, ( $3^{\text {rd }}$ edition) New Delhi

34. Lacour, M. \& Tissigton, LD. (2011). Educational research and reviews. Academic Journal, 7(9): 552-527

35. Manahan,J. (1998). The Canteen Management of Valenzuela National high School.Unpublished Master's Thesis, Meycauyan College, March 1998

36. Maniquiz, A. (2009) Canteen Administration and Operation at Maysan National High School: An Assessment. Philippine Normal University, Manila

37. Manguerra, Alberta C. Factors Associated with the Effectiveness of Cafeteria Management at the Technological University of the Philippines. March 1993

38. Medrano (2004) Level of Student's Satisfaction in TSU cafeteria Services. Retrieved from Canteen Assessment (Maysan NHS). Master Thesis. Philippine Normal University. www.scribd.com/doc/20580943/Canteen-Assessment-Maysan-NHS

39. Mendoza, M. (2004). Canteen administration and Operation in Public Elementary School in Division of Lipa City. It's Implications on the Supplementary Feeding Program of School", Unpublished Master's thesis, Tanuan Institute, March 2004 
40. Morphet (1994). Retrievd from Anthony Agbulos. Quality of Service Effectiveness of the Cafeteria Management. www.academia.edu $>$ Mareeee

41. Mugenda O. M. \& Mugenda, A.G. (2008). $2^{\text {nd }}$ Edition, Research Methods: Qualitative and QuantitativeMethods, Acts Press, Nairobi.

42. Nabarro, D., Menon, P., Ruel, M., \& Yosef, S. (2012). Scaling Up Nutrition: A global movement to accelerate progress in reducing maternal and child under nutrition. Brief 9, In: J. Linn (ed.).

43. Nadiri, H., Kandampully, J., \& Kashif, H. (2009) Students' Perception of service quality in higher education. Total Quality Management and Business Excellence

44. Orazem, P., Glewwe, P., \& Patrinos, H. (2007). The benefits and costs of alternative strategies to improve educational outcomes. Working Paper No. 07028. Ames, Iowa: Iowa State University

45. Orodho, J. A. (2004). Research Methods: Elements of Education and Social Science, Gaborone, Botswana, Mazole publication.

46. Orpilla, C. (2004). "The Performance of the Students in Orthodontics (B) and the Teacher Attributes: A correlation Study." Master's Thesis, CLSU, Muñoz, Nueva Ecija

47. Patto, MQ. (2000). Qualitative evaluation and research methods. (7 $7^{\text {th }}$ ed.). Thousand Oaks, CA: Sage Publications, INC.

48. Parasuraman AP., Zeithaml, V., \& Berry, L. (1988). SERVQUAL: A multiple-Item Scale of measuring consumer perceptions of service quality. Journal of retailing

49. Posa, R. (2004). "CSC Student Teacher and Parent Related Variables Affecting Grade one Pupil's Academic Performance." Master's Thesis, Leyte Institute of Technology, Tacloban City

50. Ray (2011) Retrieved from Food Court Administration and Operation at Nueva Ecija University of Science and Technology: An Assessment.

www.academia.edu/15003717/Food Court Administration and Op eration at?auto download=true

51. Sandstead, HHI, Penland, JG, Alcock NW. (1998). Effects of repletion with zinc and other micronutrients on neuropsychological performance and growth of Chinese children. AM J Clin Nutritional. 1998;68 (supply 2): 470S-475S. China

52. Santos, J. (2016) Assessment of Canteen Management practices in Public Elementary School: Basis for proposed Enhanced Handbook

53. Shrestha, I., \& Pathak, L. (2012). A review of the National Health Policy 1991. Kathmandu: Ministry of Health and Population

54. Indaratana Porn (2000). Retrieved from Canteen Assessment (Maysan NHS). Master Thesis. Philippine Normal University. www.scribd.com/doc/20580943/Canteen-Assessment-Maysan-NHS

55. Stevens, G., Finucane, M., Paciorek, C., Flaxman, S., White, R., Donner, A. \& Ezzati, M. (2012). Trends in mild, moderate, and severe stunting and underweight, and progress towards MDG 1 in 141 developing countries: A systematic analysis of population representative data. Lancet, 380 (7):824-834

56. Taylor, Steven. (1991) Measuring Service Quality: A Reexamination and Extension. Journal of Services Marketing.

57. The School Center Handbook (1999) Retrieved from Canteen Administration and Operation at Maysan National High School: An Assessment www. Scribd.com/doc/20580943/Canteen-AssessmentMaysan-NHS

58. Trajeco, Ma. Shirley C. (2001) "Self-concept, Academic Achievement of Anxiety Pattern of Second Year High School in Occidental Mindoro: A Correlation Study." Master's Thesis, Centro Escolar University, Manila

59. UNESCO (2011). EFA Global Monitoring Report 2011: The hidden crisis: Armed conflict. Paris UNESCO

60. Wersma, B.N (2005) Research and Statistics, an Elementary Approach and Statistics, New York, McGraw

61. Wongkhum, S. (2000). Evaluation of Wkt-Wruwa Lunch Program: saraphi District Gahang Mai Province, Unpublished Master's Thesis, 2000

62. Zeithaml, V. (1988) Consumer Perceptions of Price, Quality and Value: A means-End Model and Synthesis of Evidence. Journal of Marketing

\section{Others:}

http://www.deped.gov.ph/order/do-8-s-2007

DO 8, s. 2007 - Revised Implementing Guidelines on the Operation and Management of School Canteens in Public Elementary and Secondary Schools

http://www.gppb.gov.ph/laws/lWS/RA_6938.pdf

Republic Act no 6938

An Act to Ordain A Cooperative Code of the Philippines

http://www.lawphil.net/statues/repacts/ra2000/ra_8976_2000.html

Republic Act No. 8976 November 7, 2000
An Act Establishing The Philippine Food Fortification Program And For Other Purposes.

http://www.scribd.com/doc/20580943/Canteen-Assessment-MaysanNHS\#scribd

Canteen Administration And Operation At Maysan National high School: An Assessment. A Special Project Presented to the Faculty of College of Science Philippine Normal University Manila In Partial Fulfillment of the Requirements for the Degree Master of Education with Specialization in Home Economics by: Arlene B. Maniquiz March 2009

http://www.who.int/features/factfiles/food_safety/en/

10 Facts on Food Safety

February 2015

Girl Eating Fruits, Madagascar

International Fund for Agricultural Development

DECS Order No. 93, s 1998

Regional Memorandum No. 70 s. 2008

Schools Policy handbook, January 1998

Texas Department of Education, 2003

The School Center Handbook.

World Health Statistics

Global Health Observatory data

www.who.int

tascanteenassn.org.au

Tasmanian School Canteen Handbook

A Whole School Approach to Healthy Eating

Tasmanian School Canteen Association Inc.

\section{AUTHORS PROFILE}

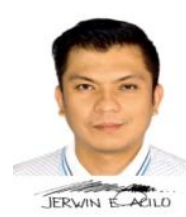

Jerwin Erum Acilo, MBA, Occupation: Senior High School Teacher, Zambales national High School

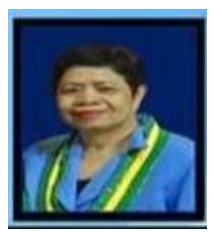

Dr. Esmen M. Cabal, Occupation: Professor at President Ramon Magsaysay State University. Number of published articles for 2021: 3 internationl

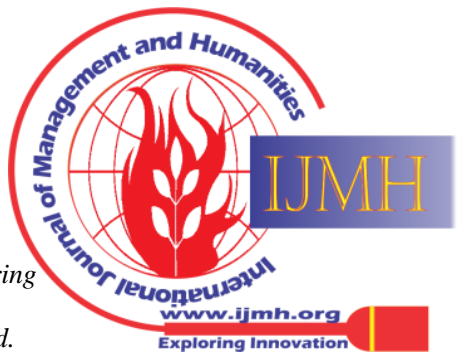

